\title{
Photosynthetic Characteristics of Four Wild Dendrobium Species in China
}

\author{
Gang-Yi Wu and Jun-Ai Hui
}

College of Life Science, South China Normal University, Guangdong Province

Key Laboratory for Biotechnology of Plant Development, Guangzhou 510631, P.R. China

\begin{abstract}
Zai-Hua Wang
College of Life Science, South China Normal University, Guangdong Province Key Laboratory for Biotechnology of Plant Development, Guangzhou 510631, P.R. China; and the Environmental Horticulture Research Institute of Guangdong Academy of Agricultural Sciences, Guangzhou 510640, China
\end{abstract}

\section{Jie Li \\ Environmental Horticulture Research Institute of Guangdong Academy of Agricultural Sciences, Guangzhou 510640, China}

\section{Qing-Sheng Ye ${ }^{1}$}

College of Life Science, South China Normal University, Guangdong Province Key Laboratory for Biotechnology of Plant Development, Guangzhou 510631, P.R. China

Additional index words. C3 pathway, Dendrobium orchid, leaf anatomical structure, net photosynthetic rate, photosynthetic physiology

\begin{abstract}
Photosynthetic physiology of Dendrobium nobile, Dendrobium pendulum, Dendrobium chrysotoxum, and Dendrobium densiflorum was studied. A bimodal diurnal variation of the net photosynthetic rate $\left(\mathrm{P}_{n}\right)$ was observed in the four Dendrobium species with the first peak [5.09 to $6.06 \mu \mathrm{mol}\left(\mathrm{CO}_{2}\right)$ per $\left.\mathrm{m}^{-2} \cdot \mathrm{s}^{-1}\right] \approx 1100 \mathrm{HR}$ and the second peak [3.83 to $4.58 \mu \mathrm{mol}\left(\mathrm{CO}_{2}\right)$ per $\mathrm{m}^{-2} \cdot \mathrm{s}^{-1}$ ] at $1500 \mathrm{Hr}$. No $\mathrm{CO}_{2}$ fixation was observed at night. For all four Dendrobium species, the light compensation point (LCP) was 5 to $10 \mu \mathrm{mol} \cdot \mathrm{m}^{-2} \cdot \mathrm{s}^{-1}$, light saturation point (LSP) ranged from 800 to $1000 \mu \mathrm{mol} \cdot \mathrm{m}^{-2} \cdot \mathrm{s}^{-1}$, apparent quantum yield (AQY) was 0.02 , and $\mathrm{CO}_{2}$ compensation points $(\mathrm{CCP})$ and saturation point (CSP) were 60 to $85 \mu \mathrm{mol} \cdot \mathrm{mol}^{-1}$ and 800 to $1000 \mu \mathrm{mol} \cdot \mathrm{mol}^{-1}$, respectively. Carboxylation efficiency (CE) values ranged from 0.011 to 0.020 . The optimum temperature for photosynthesis was between 26 and $30{ }^{\circ} \mathrm{C}$. The measurement of $P_{n}$ seasonal variation indicated that July to August had the higher $P_{n}$ for Dendrobium species. Additionally, the chlorophyll $a / b(\mathrm{Chl} a / b)$ ratios of the leaves were 2.77 to 2.89 . Measurement of key enzymes in the photosynthetic pathway indicated relatively high Ribulose-1,5-bisphosphate carboxylase (RuBPCase) and glycolate oxidase (GO) activities but very low phosphoenolpyruvate carboxylase (PEPCase) activities. It suggested that these four Dendrobium species are typical semishade $C_{3}$ plants.
\end{abstract}

The genus Dendrobium is one of the largest genera in Orchidaceae; there are $\approx 1500$ species around the world. In China there are 74 species and two varieties (belonging to nine sections) and mainly distributed in the mountain ranges of southern and western China (Tsi et al., 1999). Most Dendrobium orchids are endangered species and are overexploited as

Received for publication 27 Aug. 2013. Accepted for publication 30 May 2014.

This research was supported by the National Nature Science Foundation of China (30970215), the National Science Foundation of Guangdong Province in China (8251063101000008), and Guangdong Provincial Department of science and technology in agricultural research team project (2011A020102007).

We express our gratitude to Dr. C.S. Hew for his advice.

${ }^{1}$ To whom reprint requests should be addressed; e-mail ye-lab@scnu.edu.cn. a result of their ornamental and medicinal values, e.g., Dendrobium. nobile, D. pendulum, $D$. chrysotoxum, and D. densiflorum (Chen and Tsi, 1997). These four species all blossom in spring and can be cultivated as ornamental potted plants or used for extraction of polysaccharides and alkaloids from the stems. At present, Dendrobium is listed in the Convention on International Trade in Endangered Species of Wild Fauna and Flora. There have been considerable efforts in large-scale commercial cultivation of medicinal Dendrobium orchids. However, research on the physiology of wild Dendrobium species has been scanty, and only a few wild Dendrobium species was investigated (Chou et al., 2001; Su and Zhang, 2003a, 2003b; Zhu et al., 2013a, 2013b).

Generally, orchids can be divided into thick-leaved orchids and thin-leaved orchids according to their leaf thickness. The thickleaved orchids belong to CAM plants, e.g.,
Phalaenopsis (Endo and Ikusima, 1989), Dendrobium Phalaenopsis (He and Woon, 2008), and Cattleya (Stancato et al., 2002); and the thin-leaved orchids are C3 plants, e.g., Dendrobiums (Zhu et al., 2013a, 2013b). There are fairly extensive studies on the photosynthetic physiology of thin-leaved Oriental Cymbidium (Pan et al., 1997; Pan and Ye, 2006). The photosynthetic characteristics of thin-leaved Oncidium have also been shown to be a C3 orchid (He et al., 2011; Li et al., 2002). No C4 plant was found in Orchidaceae. In our previous studies, photosynthetic characteristics of wild Dendrobium (D. williamsoii, D. longicornu, D. chrysanthum, and D. dixanthum) in China were reported to be semishade $\mathrm{C} 3$ orchids There is no conclusive evidence to indicate that the photosynthetic pathway of wild Dendrobium species endemic to China belong to the nobile type that blossom in spring, and they are different from the CAM orchid Dendrobium, which blossom in fall (Khoo et al., 1997). More works are needed to understand the ecophysiological and photosynthetic characteristics of the wild Chinese Dendrobium orchids.

The objective of the present investigation is to carry out a systemic study of the photosynthetic characteristics of these four well-known wild Dendrobium species (D. nobile, D. pendulum, D. chrysotoxum, and D. densiflorum) in China. This study provides useful information for the conservation and rational use of these four endangered orchids.

\section{Materials and Methods}

Plant materials. Four wild Chinese Dendrobium species (D. nobile and D. pendulum in Sect. Eugenanthe; D. chrysotoxum and D. densiflorum in Sect. Callista) were collected from Yunnan Province in China and cultivated in pots using sawdust as a substrate in a greenhouse kept with $60 \%$ to $70 \%$ of shade, which provided a maximum midday light radiation intensity was $\approx 1250 \pm$ $100 \mu \mathrm{mol} \cdot \mathrm{m}^{-2} \cdot \mathrm{s}^{-1}$. The shaded greenhouse was $28 \pm 2{ }^{\circ} \mathrm{C}$ in the day and $25 \pm 3{ }^{\circ} \mathrm{C}$ at night, and relative humidity $(\mathrm{RH})$ was between $65 \%$ and $80 \%$. Plants were fertilized with one-third Hoagland nutrient solution weekly. The fourth mature leaf from the apex was selected for testing of photosynthetic characteristics in all experiments. All determinations were replicated three times.

Leaf structure. The anatomical structure of the leaves was examined under an optical microscope (DM 6000B; Leica, Germany) and a scanning electron microscope $(\mathrm{S}-3500 \mathrm{~N}$; Hitachi, Japan). Preparation of the sample for the scanning electron microscope was as described in the Cytology Laboratory, Institute of Botany, the Chinese Academy of Sciences (1974).

Measurement of photosynthetic characteristics. Various parameters including $\mathrm{P}_{\mathrm{n}}$, stomatal conductance, intercellular $\mathrm{CO}_{2}$ concentration, transpiration rate $\left(\mathrm{T}_{\mathrm{r}}\right)$, photosynthetically active radiation $(P A R)$, and air temperature were measured simultaneously by an LI-6400 portable photosynthetic system (LI-COR). 
Light-response curve. Measurement was conducted between $0930 \mathrm{HR}$ and $1130 \mathrm{HR}$. Using the automatic measurement function of the light response curve of the LI-6400 photosynthesis system, the built-in red and blue light sources (6400-02B) were set at a series of $P A R$ gradients within the range of 0 to $1200 \mu \mathrm{mol} \cdot \mathrm{m}^{-2} \cdot \mathrm{s}^{-1}$, and the leaf $\mathrm{P}_{\mathrm{n}}$ corresponding to each gradient was measured. The corresponding curve was plotted with the paired values of $\mathrm{P}_{\mathrm{n}}$ and $P A R$, and the LCP, LSP, and related parameters were obtained. Linear regression was performed on the paired values of $P A R$ and $\mathrm{P}_{\mathrm{n}}$ below $200 \mu \mathrm{mol} \cdot \mathrm{m}^{-2} \cdot \mathrm{s}^{-1}$, and the initial slope of the response curve $\mathrm{P}_{\mathrm{n}}$ $P A R$ was the AQY of photosynthesis. For photosynthesis measurement, the $\mathrm{CO}_{2}$ concentration was set at $380 \pm 10 \mu \mathrm{mol} \cdot \mathrm{mol}^{-1}$, leaf chamber temperature at $25 \pm 0.5^{\circ} \mathrm{C}$, and $\mathrm{RH}$ at $70 \pm 15 \%$.

$\mathrm{CO}_{2}$-response curve. The $\mathrm{CO}_{2}$ concentration was regulated using the injection function (6400-01) of the LI-6400 portable photosynthesis system. The $P A R$ was maintained at $800 \pm 10 \mu \mathrm{mol} \cdot \mathrm{m}^{-2} \cdot \mathrm{s}^{-1}$, temperature at $25 \pm 0.5^{\circ} \mathrm{C}$, and $\mathrm{RH}$ at $70 \pm 15 \%$. The $\mathrm{CO}_{2}$ concentration gradients were set within the range of 0 to $1500 \mu \mathrm{mol} \cdot \mathrm{mol}^{-1}$ and the $P_{n}$ corresponding to each gradient was measured. The corresponding curve was plotted with the paired values of $\mathrm{P}_{\mathrm{n}}$ and $P A R$, and the CCP, CSP, and related parameters were acquired. Linear regression was performed on the paired values of $\mathrm{CO}_{2}$ concentration and $\mathrm{P}_{\mathrm{n}}$ below $200 \mu \mathrm{mol} \cdot \mathrm{m}^{-2} \cdot \mathrm{s}^{-1}$, and the initial slope was the CE of RuBPCase. The
$\mathrm{P}_{\mathrm{n}}$ at the $\mathrm{CO}_{2}$ light saturation point was the regenerating rate of RuBP.

Temperature response curve. The $\mathrm{P}_{\mathrm{n}}$ value of each temperature gradient within the range of 18 to $34{ }^{\circ} \mathrm{C}$ was measured from low to high temperature using the leaf chamber temperature adjustment function (6400-13) of the LI-6400 portable photosynthesis system. During the measurements, $P A R$ was set at $800 \pm$ $10 \mu \mathrm{mol} \cdot \mathrm{m}^{-2} \cdot \mathrm{s}^{-1}, \mathrm{CO}_{2}$ concentration at $380 \pm$ $10 \mu \mathrm{mol} \cdot \mathrm{mol}^{-1}$, and $\mathrm{RH}$ at $70 \pm 15 \%$.

Measurement of $P_{n}$ diurnal variation and seasonal variation. For measurement of diurnal variation, the $P_{n}$ and the related parameters were measured from $0700 \mathrm{HR}$ to $1900 \mathrm{HR}$ during 3 sunny days in the middle of May. The $\mathrm{P}_{\mathrm{n}}$ seasonal variations were measured under natural conditions at $1000 \mathrm{HR}$ to $1100 \mathrm{HR}$ on
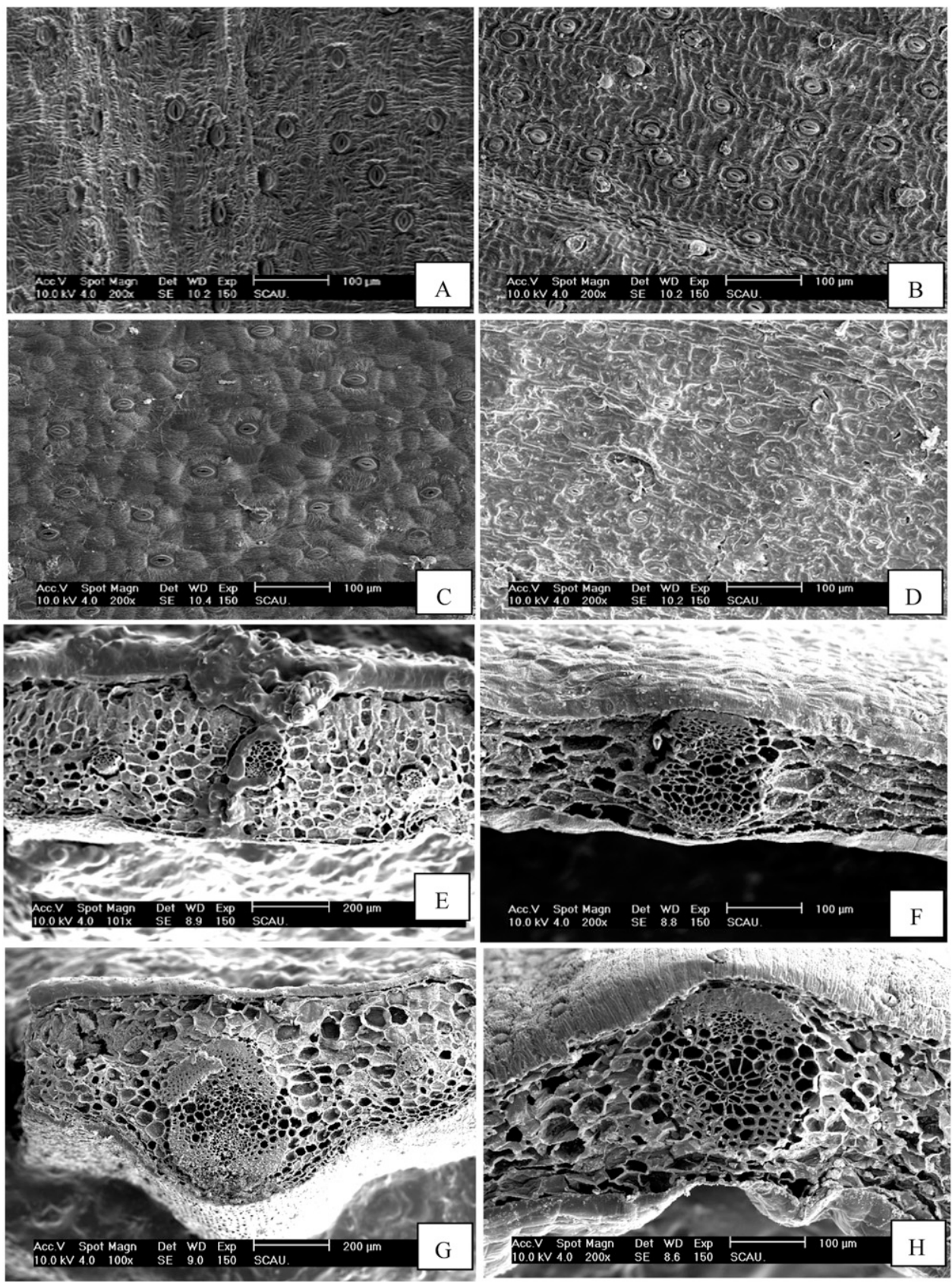

Fig. 1. Electron microscope images of the abaxial surface (A-D) and cross-section (E-H) of leaves of the four Dendrobium species. (A, E) Dendrobium nobile; (B, F) Dendrobium pendulum; (C, G) Dendrobium chrysotoxum; $(\mathbf{D}, \mathbf{H})$ Dendrobium densiflorum. 
3 sunny days in the middle of each month from January to October.

Measurement of chlorophyll content. Chlorophyll measurement was done according to methods described by Wintermans and De Mots (1965).

Enzyme extraction and activity determination. Leaves of each Dendrobium species were illuminated for $2 \mathrm{~h}$ before enzyme extract. The sliced leaf tissues $(0.2 \mathrm{~g})$ were grounded in $1.5 \mathrm{~mL}$ of pre-cooled $100 \mathrm{~mm}$ Tris-HCL buffer solution (containing $10 \mathrm{~mm}$ $\mathrm{MgCl}_{2}, 5 \mathrm{~mm}$ mercaptoethanol, 1 mm EDTA, $12.5 \%$ glycerol, and $1 \%$ PVP, $\mathrm{pH} 7.4$ ) with $\mathrm{N}_{2}$ in a semimicro Waring blender for $3 \mathrm{~min}$. The homogenates were filtered through four layers cheesecloth and then centrifuged at 15,000 $\mathrm{rpm}$ for $20 \mathrm{~min}$ at $4{ }^{\circ} \mathrm{C}$. The supernatant was used for testing enzyme activity of RuBPCase (EC 4.1.1.39), PEPCase (EC 4.1.1.31), and GO (EC 1.1.3.1) (Zhang, 1990).

Determination of protein content. The protein content in the enzyme extracts was determined by Coomassie brilliant blue staining, and the standard curve was plotted using bovine serum albumin.
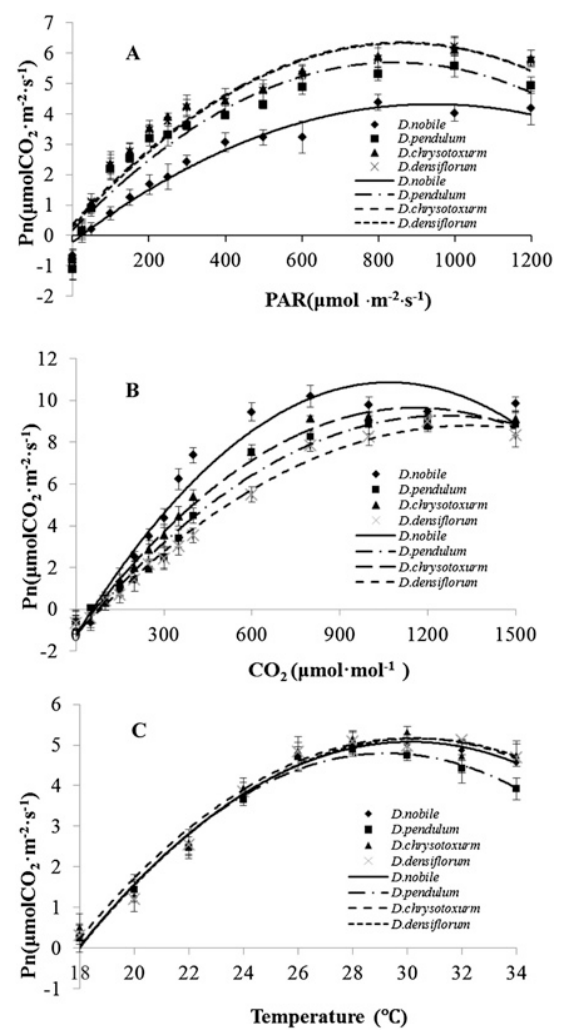

Fig. 2. Light intensity (A), $\mathrm{CO}_{2}$ concentration (B), and temperature $(\mathbf{C})$ response curves of the leaves of the four Dendrobium species.

\section{Results}

Anatomical structure of Dendrobium species leaves. Dendrobium showed bifacial anatomy with thin leaves $\approx 800 \pm 50 \mu \mathrm{m}$ (Fig. 1E-H), suggesting these species were thin-leaved orchids compared with thickleaved CAM orchids such as Phalaenopsis amabilis, which have a leaf thickness of $\approx 3000 \mu \mathrm{m}$ (Endo and Ikusima, 1989). The adaxial epidermis cells of the leaves were covered by cuticle with no stomata. These cells were larger and square in shape and formed a single layer of cells $\approx 20 \mu \mathrm{m}$ thick, which arranged in an orderly rectangular pattern. The abaxial epidermis cells were irregular in shape and sizes with stomatal intensities ranging from 110 to $130 \mathrm{~mm}^{-2}$. The stomata were elliptical and the guard cell length and width were $\approx 30 \mu \mathrm{m}$ and $20 \mu \mathrm{m}$, respectively. All stomata were slightly sunken into the leaf epidermis and were covered by a waxy stomatal cover (Fig. 1A-D). The mesophyll tissue was well developed and differentiated into palisade and spongy tissues (Fig. 1E-H). The palisade tissue was composed of one to two layers of orderly arranged cylindrical cells with thickness of $60 \mu \mathrm{m}$. The cells in the outer layer were densely arranged, deeply stained, and idioblast-shaped, whereas the cells in the inner layer were lightly stained and contained abundant chloroplasts. The spongy tissue cells were loosely arranged with a layer thickness of $40 \mu \mathrm{m}$ and also contained many chloroplasts. The vascular bundles were arranged in a ring and the parenchyma cells in the bundle sheath were relatively small and distinctively arranged, containing no chloroplasts. No Kranz leaf anatomy was observed. Therefore, the anatomical structure of these four Dendrobium species indicated they were typical semishade $\mathrm{C}_{3}$ plants.

Light intensity, $\mathrm{CO}_{2}$, and temperature response curves of the Dendrobium leaves. The four species exhibited similar $\mathrm{P}_{\mathrm{n}}-P A R$ curves (Fig. 2A). Within 0 to $300 \mu \mathrm{mol} \cdot \mathrm{m}^{-2} \cdot \mathrm{s}^{-1}$, $\mathrm{P}_{\mathrm{n}}$ increased linearly, but the increased rates became slow when PAR ranged from 300 to $600 \mu \mathrm{mol} \cdot \mathrm{m}^{-2} \cdot \mathrm{s}^{-1}$; the $\mathrm{P}_{\mathrm{n}}$ reached its peak at $P A R$ of $800 \mu \mathrm{mol} \cdot \mathrm{m}^{-2} \cdot \mathrm{s}^{-1}$ and began to decrease with the increase of $P A R$. The maximum of $\mathrm{P}_{\mathrm{n}}, \mathrm{LCP}$, and LSP for the four Dendrobium species was 5 to $6 \mu \mathrm{mol}\left(\mathrm{CO}_{2}\right)$ per $\mathrm{m}^{-2} \cdot \mathrm{s}^{-1}, 5$ to $8 \mu \mathrm{mol} \cdot \mathrm{m}^{-2} \cdot \mathrm{s}^{-1}$, and 800 to $1000 \mu \mathrm{mol} \cdot \mathrm{m}^{-2} \cdot \mathrm{s}^{-1}$, respectively (Fig. 2A; Table 1). Maximum photosynthetic rate reflected leaf photosynthetic efficiency, and $D$. chrysotoxum had the higher photosynthetic efficiency $\left[5.89 \mu \mathrm{mol}\left(\mathrm{CO}_{2}\right)\right.$ per $\left.\mathrm{m}^{-2} \cdot \mathrm{s}^{-1}\right]$ and the highest demand for light, whereas
D. nobile had the lowest photosynthetic potential $\left[4.38 \mu \mathrm{mol}\left(\mathrm{CO}_{2}\right)\right.$ per $\left.\mathrm{m}^{-2} \cdot \mathrm{s}^{-1}\right]$. Generally, the four Dendrobium species have relatively low LSPs and LCPs, which reflect their shade habit. In addition, AQY is a key index for the light use efficiency of leaves that reflects the ability of leaves to use dim light. The AQYs of the four Dendrobium species were $\approx 0.02$ and no significant differences were observed among the four Dendrobium species, which indicated that they had relatively low light use efficiency but relatively high requirements for the light quantum for photosynthesis.

The photosynthetic rates of the four Dendrobium species showed almost identical responses to $\mathrm{CO}_{2}$ concentration (Fig. 2B; Table 1) and their CCPs were between 60 and $90 \mu \mathrm{mol} \cdot \mathrm{mol}^{-1}$. For $\mathrm{CO}_{2}$ in the range of 0 to $700 \mu \mathrm{mol} \cdot \mathrm{mol}^{-1}$, the photosynthetic rates of the four species increased rapidly with increasing $\mathrm{CO}_{2}$ concentration. The $\mathrm{P}_{\mathrm{n}}$ peaked at $\approx 9$ to $10 \mu \mathrm{mol}\left(\mathrm{CO}_{2}\right)$ per $\mathrm{m}^{-2} \cdot \mathrm{s}^{-1}$ in $\mathrm{CO}_{2}$ concentrations of $800 \mu \mathrm{mol} \cdot \mathrm{mol}^{-1}$, indicating that the $\mathrm{CO}_{2}$ saturation points of the Dendrobium species were in the range of 800 to $1000 \mu \mathrm{mol} \cdot \mathrm{mol}^{-1}$. The CEs of the four Dendrobium species were $\approx 0.011$ to 0.020 , showing their ability to low use of $\mathrm{CO}_{2}$. High $\mathrm{CO}_{2}$ concentration significantly increased the photosynthetic rates of these species. Temperature was the main influencing factor for the photosynthetic rate of plants. The $P_{n}$ for the four Dendrobium species increased linearly with a rise in temperature between 18 and $26{ }^{\circ} \mathrm{C}$ and peaked at 28 to $30{ }^{\circ} \mathrm{C}$. The maximum $\mathrm{P}_{\mathrm{n}}$ of the four Dendrobium species were between 4.89 and $5.31 \mu \mathrm{mol}\left(\mathrm{CO}_{2}\right)$ per $\mathrm{m}^{-2} \cdot \mathrm{s}^{-1}$ (Fig. 2C). The $\mathrm{P}_{\mathrm{n}}$ decreased when temperature was over $30{ }^{\circ} \mathrm{C}$, indicating that the optimum temperatures for Dendrobium photosynthesis were in the range of 26 to $30^{\circ} \mathrm{C}$.

$P_{n}$ diurnal and annual variation of the four Dendrobium species. The diurnal variation in the photosynthetic rates of the four Dendrobium species showed the same bimodal curve (Fig. 3). There was an rapid increase of $\mathrm{P}_{\mathrm{n}}$ from $700 \mathrm{~h}$, reaching a peak of 5.09 to $6.06 \mu \mathrm{mol}\left(\mathrm{CO}_{2}\right)$ per $\mathrm{m}^{-2} \cdot \mathrm{s}^{-1} \approx 1100 \mathrm{HR}$ but then decreased thereafter, and dropped to a minimum at $1300 \mathrm{HR}$ to $1400 \mathrm{HR}$ (Fig. 3A). From 1100 HR to 1300 HR, the environmental PAR and temperature rose continuously and exceeded the optimum conditions for Dendrobium photosynthesis. The high $P A R$ and temperature exerted stress on the plant resulting in an increase in stomatal resistance, a decrease in $\mathrm{CO}_{2}$ absorption, and an increased of $\operatorname{Tr}$ (Fig. 3B-D), which, in turn, caused "midday depression." The second $\mathrm{P}_{\mathrm{n}}$

Table 1. Characteristics of light and $\mathrm{CO}_{2}$ responses of the leaves of the four Dendrobium species.

\begin{tabular}{|c|c|c|c|c|c|c|}
\hline \multirow[b]{2}{*}{ Species } & \multicolumn{3}{|c|}{ Characteristics of light response } & \multicolumn{3}{|c|}{ Characteristics of $\mathrm{CO}_{2}$ response } \\
\hline & $\overline{\mathrm{LCP}}\left(\mu \mathrm{mol} \cdot \mathrm{m}^{-2} \cdot \mathrm{s}^{-1}\right)$ & $\mathrm{LSP}\left(\mu \mathrm{mol} \cdot \mathrm{m}^{-2} \cdot \mathrm{s}^{-1}\right)$ & AQY & $\overline{\mathrm{CCP}}\left(\mu \mathrm{mol} \cdot \mathrm{mol}^{-1}\right)$ & $\mathrm{CSP}\left(\mu \mathrm{mol} \cdot \mathrm{mol}^{-1}\right)$ & $\mathrm{CE}$ \\
\hline$\overline{\text { Dendrobium nobile }}$ & $5.39 \pm 0.21$ & $900 \pm 50$ & $0.021 \pm 0.003$ & $79.66 \pm 5.51$ & $800 \pm 50$ & $0.020 \pm 0.003$ \\
\hline Dendrobium pendulum & $7.28 \pm 0.17$ & $800 \pm 50$ & $0.020 \pm 0.001$ & $66.27 \pm 6.12$ & $900 \pm 50$ & $0.011 \pm 0.002$ \\
\hline Dendrobium chrysotoxum & $5.01 \pm 0.34$ & $950 \pm 50$ & $0.021 \pm 0.003$ & $77.54 \pm 4.83$ & $850 \pm 50$ & $0.016 \pm 0.003$ \\
\hline Dendrobium densiflorum & $6.14 \pm 0.22$ & $850 \pm 50$ & $0.021 \pm 0.003$ & $84.46 \pm 5.48$ & $950 \pm 50$ & $0.012 \pm 0.001$ \\
\hline
\end{tabular}

$\mathrm{LCP}=$ light compensation point; $\mathrm{LSP}=$ light saturation point; $\mathrm{AQY}=$ apparent quantum yield; $\mathrm{CCP}=\mathrm{CO}{ }_{2}$ compensation point; $\mathrm{CSP}=\mathrm{CO}{ }_{2}$ saturation point; $\mathrm{CE}=$ carboxylation efficiencies. 
peak $\left[3.83\right.$ to $4.58 \mu \mathrm{mol}\left(\mathrm{CO}_{2}\right)$ per $\mathrm{m}^{-2} \cdot \mathrm{s}^{-1}$ ] began at $1500 \mathrm{HR}$ to $1600 \mathrm{HR}$, after which $\mathrm{P}_{\mathrm{n}}$ rapidly decreased. Furthermore, it showed that the four Dendrobium species showed no $\mathrm{CO}_{2}$ absorption at night at our preliminary experiment (unpublished data). Therefore, these four species were $\mathrm{C} 3$ rather than CAM plants.

The $\mathrm{P}_{\mathrm{n}}$ of the four Dendrobium species had relatively similar seasonal variation patterns (Fig. 4) with the highest value in June [the peak values of $D$. nobile, $D$. pendulum, $D$. chrysotoxum, and D. densiflorum were 5.87, 5.51, 6.27, and $6.22 \mu \mathrm{mol}\left(\mathrm{CO}_{2}\right)$ per $\mathrm{m}^{-2} \cdot \mathrm{s}^{-1}$, respectively]. Measurement of seasonal phoOctober and the photosynthesis rates of these Dendrobium species were higher during May to August, which may be correlated with temperature, light intensity, and leaf maturity. tosynthesis was carried out from January to

The $P_{n}$ during March and April was relatively low, which may be the result of the low temperature or immature leaves during this period.

Variation of chlorophyll content and activities of key photosynthetic enzymes. The $\mathrm{Chl} a / b$ ratios of the four Dendrobium species were varied from 2.77 to 2.89 (Table 2). Measurement of enzyme activities (Table 3) indicated that PEPCase activity in the four Dendrobium species were very low, all within a range of 1.2 to $1.3 \mathrm{nmol}\left(\mathrm{CO}_{2}\right) / \mathrm{mg}$ (protein) $/ \mathrm{min}$.

\section{Discussion}

The photosynthesis of tropical orchids has been studied and documented (Hew and Yong, 1997). Generally thin-leaved orchids are $C_{3}$
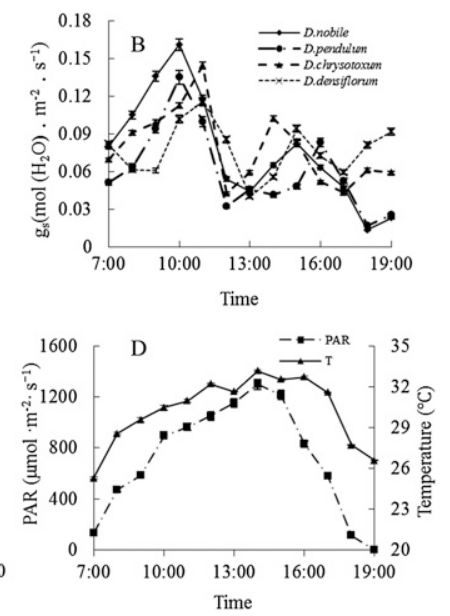

Fig. 3. Diurnal variation of net photosynthetic rate $\left(\mathrm{P}_{\mathrm{n}}\right)(\mathbf{A})$, stomatal conductance $\left(g_{\mathrm{S}}\right)(\mathbf{B})$, transpiration rate $\left(\mathrm{T}_{\mathrm{r}}\right)(\mathbf{C})$, and environmental photosynthetically active radiation (PAR) (D) of the leaves of the four Dendrobium species.

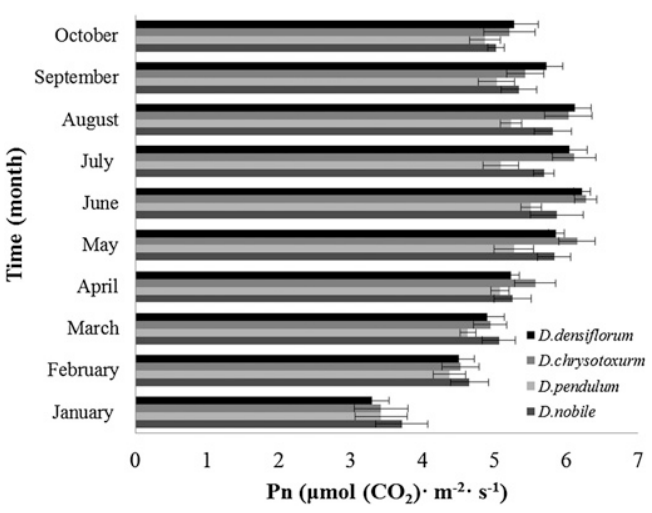

Fig. 4. Seasonal variation of net photosynthetic rate $\left(\mathrm{P}_{\mathrm{n}}\right)$ of the four Dendrobium species.

Table 2. Variation of chlorophyll content in leaves of four Dendrobium species.

\begin{tabular}{lcccc}
\hline & \multicolumn{2}{c}{ chlorophyll content $\left(\mathrm{mg} \cdot \mathrm{g}^{-1} \mathrm{FW}\right)$} & \\
\cline { 2 - 4 } Species & $\mathrm{Chl} a$ & $\mathrm{Chl} b$ & Total Chl & Chl $a / b$ \\
\hline Dendrobium nobile & $1.28 \pm 0.05$ & $0.46 \pm 0.02$ & $1.75 \pm 0.03$ & 2.78 \\
Dendrobium pendulum & $1.27 \pm 0.01$ & $0.46 \pm 0.02$ & $1.73 \pm 0.01$ & 2.77 \\
Dendrobium chrysotoxum & $0.95 \pm 0.01$ & $0.33 \pm 0.05$ & $1.28 \pm 0.03$ & 2.89 \\
Dendrobium densiflorum & $1.32 \pm 0.01$ & $0.45 \pm 0.01$ & $1.75 \pm 0.02$ & 2.88 \\
\hline
\end{tabular}

$\mathrm{FW}=$ fresh weight; $\mathrm{Chl}=$ chlorophyll. plants, whereas thick-leaved orchids are CAM plant. To date, no $\mathrm{C}_{4}$ orchid has been reported (Pan et al., 1997; Pan and Ye, 2006; Ye et al., 1993). The four Dendrobium species have bifacial leaf structure and are thin-leaved orchids. No Kranz structure that displayed the characteristics of $\mathrm{C}_{3}$ plants in the vascular bundle sheath cells was observed (Fig. 1E-H). Furthermore, the photosynthetic characteristics, especially the high CCP and CSP (Table 1) and low PEPCase activity (Table 3), demonstrated that these studied species were C3 plants and not $\mathrm{C}_{4}$ or CAM orchids. Our results differ from that of $\mathrm{Su}$ and Zhang (2003a, 2003b) who stated that D. nobile and D. officinale have a facultative CAM photosynthetic pathway (transformation of photosynthesis pathway in the CAM pathway and C3 pathway) but were similar to our previous results that the four Dendrobium species (D. williamsonii, D. longicornu, D. chrysanthum, and $D$. dixanthum) were $\mathrm{C} 3$ plants (Zhu et al., 2013a, 2013b). The $P_{n}$ diurnal variation of the leaves of the four Dendrobium species showed bimodal curves with a noticeable "midday depression" (Fig. 3A). That phenomenon is a known light defense mechanism that protects the plant's photosynthetic apparatus from damage resulting from high $P A R$ and temperature (Edwards and Walker, 1985). The LSPs of the four Dendrobium species were $40 \%$ to $50 \%$ (Table 1 ) of maximum light intensity (1800 to $2200 \mu \mathrm{mol} \cdot \mathrm{m}^{-2} \cdot \mathrm{s}^{-1}$ ), indicating that the Dendrobium species exhibited characteristics of shade plants. The optimum temperature of photosynthesis for these Dendrobium plants ranged from 26 to $30{ }^{\circ} \mathrm{C}$ (Fig. 2C), indicating they should be suitable for growing in the subtropical and tropical area. These results are consistent with the optimum temperature range reported for the photosynthesis of $D$. chrysanthum and $D$. dixanthum (26 to $30{ }^{\circ} \mathrm{C}$; Zhu et al., 2013b). The $\mathrm{CO}_{2}$ response curves showed that the photosynthetic rates improved with increasing $\mathrm{CO}_{2}$ concentration, and the photosynthetic rates in CSPs were nearly twice (Fig. 2B; Table 1) as great as that of atmospheric $\mathrm{CO}_{2}$ concentration $\left(370 \mu \mathrm{mol} \cdot \mathrm{mol}^{-1}\right)$. Meanwhile, the values of $\mathrm{Chl} a / b$ ratio (2.77 to 2.89) of these plants (Table 2) also showed the characteristic of $\mathrm{C}_{3}$ plants (Hew and Yong, 1997). Moreover, the $P_{n}$ seasonal variation of the four Dendrobium species showed that the most vigorous growth was exhibited in May to August with the peak values of $D$. nobile, $D$. pendulum, D. chrysotoxum, and D. densiflorum being 5.80, 5.28, 6.14, and $6.06 \mu \mathrm{mol}\left(\mathrm{CO}_{2}\right)$ per $\mathrm{m}^{-2} \cdot \mathrm{s}^{-1}$, respectively (Fig. 4). Finally, PEPCase is a key enzyme for $\mathrm{C}_{4}$ plants, and its activity has been measured at over $100 \mathrm{nmol}\left(\mathrm{CO}_{2}\right) / \mathrm{mg}$ (protein)/ min in the leaves of $\mathrm{C}_{4}$ sugarcane plant (Ye et al., 1993). In our present study, PEPCase is usually very low [1.2 to $1.3 \mathrm{nmol}\left(\mathrm{CO}_{2}\right) / \mathrm{mg}$ (protein) $/ \mathrm{min}$ ], similar to $\mathrm{C}_{3}$ plants (Table $3)$. Those results are consistent with previous findings (Edwards and Walker, 1985) as well as our own previous research on Cymbidium species (Ye et al., 1993) and Dedrobium species (Zhu et al., 2013a, 2013b). Their relatively high 
Table 3. Variation of the activities of key photosynthetic enzymes in leaves of four Dendrobium species.

\begin{tabular}{lccr}
\hline Species & PEPCase $(\mathrm{nmol} \mathrm{CO} / \mathrm{mg}$ protein $/ \mathrm{min})$ & $\mathrm{RuBPCase}(\mathrm{nmol} \mathrm{CO} / \mathrm{mg}$ protein $/ \mathrm{min})$ & $\mathrm{GO}(\mu \mathrm{mol}$ glyoxylate $/ \mathrm{mg}$ protein $/ \mathrm{min})$ \\
\hline Dendrobium nobile & $1.3 \pm 0.11$ & $33.7 \pm 0.33$ & $15.6 \pm 0.24$ \\
Dendrobium pendulum & $1.3 \pm 0.08$ & $32.2 \pm 0.29$ & $13.8 \pm 0.19$ \\
Dendrobium chrysotoxum & $1.2 \pm 0.17$ & $34.3 \pm 0.31$ & $15.2 \pm 0.17$ \\
Dendrobium densiflorum & $1.2 \pm 0.13$ & $33.4 \pm 0.36$ & $14.2 \pm 0.26$ \\
\hline
\end{tabular}

PEPCase $=$ phosphoenolpyruvate carboxylase RuBPCase $=$ ribulose-1,5-biphosphate carboxylase GO = glycolate oxidase .

RuBPCase and GO activities further supported that they were typical $\mathrm{C}_{3}$ plants with high photorespiration rates, results also similar to our previous studies (Zhu et al., 2013a, 2013b).

This study revealed for the four Dendrobium species were $\mathrm{C}_{3}$ plants, which would help in improving the cultivation techniques for their ex situ conservation as well as increase sustainable production. The correlation between the photosynthetic rate and environmental factors in the leaves of the four Dendrobium species indicated that $\mathrm{CO}_{2}$ concentration, air temperature, and light intensity were very important for the growth of those plants. To clarify systematically the rule of Dendrobium blooming in spring photosynthesis pathway, it is necessary to continue to investigate the photosynthetic characteristics of more Chinese Dendrobium species that blossom in spring.

\section{Literature Cited}

Chen, S.H. and Z.H. Tsi. 1997. The orchids of China. China Forestry Publisher, Beijing, China [in Chinese].

Chou, M.X., L.Q. Zhu, Y.J. Zhang, M. Zhang, Z.L. Bie, S.J. Chen, and Q.S. Li. 2001. Effect of light intensities and temperatures on growth of Dendrobium nobile Lindl. Chinese J. Plant Ecol. 23:325-330 [in Chinese].

Cytology Laboratory, Institute of Botany, the Chinese Academy of Sciences. 1974. Scanning electron microscope was applied in the botany. China Science Press, Beijing, China [in Chinese].

Edwards, G. and D. Walker. 1985. C 3 , C 4 : Mechanisms and cellular and environmental regulation of photosynthesis. Oxford, Blackwell, UK. p. 542.

Endo, M. and I. Ikusima. 1989. Diurnal rhythm and characteristics of photosynthesis and respiration in the leaf and root of a Phalaenopsis plant. Plant Cell Physiol. 30:43-48.

He, J., B.H.G. Tan, and L. Qin. 2011. Source-to-sink relationship between green leaves and green pseudobulbs of $\mathrm{C} 3$ orchid in regulation of photosynthesis. Photosynthetica 49:209-218.

He, J. and W.L. Woon. 2008. Source-to-sink relationship between green leaves and green petals of different ages of the CAM orchid Dendrobium cv. Burana Jade. Photosynthetica 46:91-97.

Hew, C.S. and J.W.H. Yong. 1997. The physiology of tropical orchids in relation to the industry. World Sci. Publ., Singapore.

Khoo, G.H., J. He, and C.S. Hew. 1997. Photosynthetic utilization of radiant energy by CAM Dendrobium flowers. Photosynthetica 34:367376.

Li, C.R., Y.H. Liang, and C.S. Hew. 2002. Responses of Rubisco and sucrose-metabolizing enzymes to different $\mathrm{CO} 2$ in a $\mathrm{C} 3$ tropical epiphytic orchid Oncidium Goldiana. Plant Sci. 163:313-320.

Pan, R.Z. and Q.S. Ye. 2006. Physiology of Cymbidium. China Science Press, Beijing, China [in Chinese].

Pan, R.Z., Q.S. Ye, and C.S. Hew. 1997. Physiology of Cymbidium sinense. A review. Scinetia Horticulturea. 70:123-129.
Stancato, G.C., P. Mazzafera, and M.S. Buckeridge. 2002. Effects of light stress on the growth of the epiphytic orchid Cattleya forbesii Lindl. $\times$ Laelia tenebrosa Rolfe. Brazilian Journal of Botany. 25:229-235.

Su, W.H. and G.F. Zhang. 2003a. Primary study on photosynthetic characteristics of Dendrobium nobile. J. Chinese Med Mat. 26:157-159 [in Chinese].

$\mathrm{Su}$, W.H. and G.F. Zhang. 2003b. The photosynthesis pathway in leaves of Dendrobium officinale. Chinese J. Plant Ecol. 27:631-637 [in Chinese].

Tsi, Z.H., S.C. Chen, Y.B. Luo, and G.H. Zhu. 1999. In: Tsi, Z.H. (ed.). Angiospermae, Monocotyledoneae, Flora reipublicae popularis sinicae. Vol. 19. Science Press, Beijing, China [in Chinese]

Wintermans, J.F.G.M. and A. De Mots. 1965 Spectrophotometric characteristics of chlorophylls $\mathrm{a}$ and $\mathrm{b}$ and their pheophytins in ethanol. Biochim. Biophys. Acta 109:448-453.

Ye, Q.S., R.C. Pan, and C.S. Hew. 1993. Study on the photosynthetic pathway of Cymbidium sinense. J. Integr. Plant Biol. 35:441-446 [in Chinese].

Zhang, Z.L. 1990. Laboratory precedure for plant physiology. 2nd Ed. Higher Education Press [in Chinese].

Zhu, Q.L., J.Y. Leng, and Q.S. Ye. 2013a. Photosynthetic characteristics of Dendrobium williamsonii and Dendrobium longicornu. Chinese Bulletin of Botany. 48:151-159 [in Chinese]

Zhu, Q.L., J.Y. Leng, and Q.S. Ye. 2013b. Study on photosynthetic characteristics of Dendrobium chrysanthum and Dendrobium dixanthum. Journal of South China Normal University 45:98-103 [in Chinese]. 